\title{
Insect-proof netting technique: Effective control of Bemisia tabaciand Tomato chlorosis virus (ToCV) in protected cultivations in China
}

\author{
Fan Wang ${ }^{1}$, Jin Liu ${ }^{1}$, Yonghao Dong ${ }^{1}$, Peng Chen ${ }^{1}$, Xiaoping Zhu ${ }^{1}$, Yongjie Liu ${ }^{1 *}$, and Jingyu Ma ${ }^{2}$ \\ ${ }^{1}$ Shandong Agricultural University, Key Laboratory for Biology of Vegetable Diseases and Insect Pests, Shandong Tai'an \\ 271018, PR China. *Corresponding author (lyj@sdau.edu.cn). \\ ${ }^{2}$ Jining Academy of Agricultural Science, Shandong Jining 272000, PR China.
}

Received: 19 August 2017; Accepted: 15 December 2017; doi:10.4067/S0718-58392018000100048

\section{ABSTRACT}

Bemisia tabaci (Gennadius), the vector of Tomato chlorosis virus (ToCV), is one of the major pests of tomato (Solanum lycopersicum L. var. lycopersicum), potentially causing up to $100 \%$ yield loss. The purpose of this research was to effectively reduce intrusion by $\mathrm{B}$. tabaci and control damage from ToCV in protected cultivations. The treatments included the use of a regular solar greenhouse as a control (CK); greenhouses I and II with 60- and 80-mesh insect-proof nets, respectively, that were installed in both houses at the front and upper ventilations; and greenhouse III with the addition of not only the 80-mesh insect-proof net as in greenhouse II but also a ventilating pipeline to the back wall. The effects of mesh size and back wall ventilation on the greenhouse temperature and humidity, number of B. tabaci, and level of ToCV infection were studied. Under all conditions tested (from 20142016), the temperature of greenhouse III with installed netting was reduced by drilling holes through the back wall and nonsignificant difference existed in the average relative humidity between greenhouses II and III. Importantly, the number of B. tabaci and ToCV infection rate were effectively controlled in greenhouse III, ranging from 0.03 to 0.33 adults per sampled plant and from $0 \%$ to $6.67 \%$ of virus incidence. Thus, installing 80 -mesh insect-proof netting at the front and upper ventilation areas as well as adding a ventilating pipeline to the back wall could effectively reduce the number of $B$. tabaci and prevent ToCV damage.

Key words: Bemisia tabaci, greenhouse, insect-proof net, prevention and control technique, Tomato chlorosis virus.

\section{INTRODUCTION}

Bemisia tabaci (Gennadius) is a species complex composed of at least 36 biotypes (Hu et al., 2011). Damage from B. tabaci has occurred in various countries and regions, including Africa, the Middle East, and USA (Boykin et al., 2007; Dinsdale et al., 2010; De Barro et al., 2011). Bemisia tabaci not only causes sooty mold, mainly by piercing plants to suck their juice and honeydew, but also spreads plant viruses that damage crops, vegetables, and ornamental flowers, resulting in economical loss (Byrne and Bellows, 1991; Cahill et al., 1996). Among these consequences, the damage resulting from the spread of plant viruses is the most severe. Bemisia tabaci is the only insect vector for the spread of Begomoviruses in the family Geminiviridae and is now known to be capable of spreading 200 viral diseases.

Tomato chlorosis virus (ToCV) can infect 25 plants in seven families, such as Solanaceae and Asteraceae. The virus is spread naturally through such insects as B. tabaci, Trialeurodes abutilonea, and Trialeurodes vaporariorum (Wintermantel and Wisler, 2006). ToCV was first reported in Florida, USA (Wisler et al., 1998), 
and is currently distributed in various countries globally (Zhou et al., 2014). In China, ToCV was also reported in Taiwan (Tsai et al., 2004), followed by its detection on greenhouse-cultivated tomato plants in Beijing (Zhao et al., 2013), Jiangsu (Karwitha et al., 2014), Shandong (Zhao et al., 2014), and Hebei (Sun et al., 2015). The occurrence rate also shows an increasing trend. In our field study during 2014-2016, the whiteflies on greenhouse tomatoes were found to be mainly B. tabaci. Emphasis should be placed on controlling B. tabaci infestations when controlling for viral damage.

Currently, pesticide use is the main method for preventing B. tabaci infestations. However, excessive pesticide use can lead to various problems, including not only pesticide residues, environmental contamination and food safety issues but also pesticide resistance development in B. tabaci (Fernández et al., 2009; Schuster et al., 2010; Luo et al., 2010; Wang et al., 2010). Studies concerning comprehensive methods centered on physical and biological controls could resolve the potential threats brought by chemical control methods. Scholars internationally have proposed prevention plans that implement single or multiple methods, such as agricultural control, physical control, and biological control. These methods include the management of $B$. tabaci by the combined use of insect-proof netting and aromatic plants (Mutisya et al., 2016); UV-absorbing plastic films of different specifications (Zhu et al., 2016); novel pyrethroid-treated, insect-proof nets (Dáder et al., 2015); and the combined use of yellow sticky traps and Eretmocerus nr. rajasthanicus (Gu et al., 2008).

Among the present control methods, physical control reduces the occurrence of insect infestation and viral diseases by blocking pests from entering greenhouses via the use of screens constructed with insect-proof netting. Such a technique is widely employed in the field for pest control (Saidi et al., 2013; Dáder et al., 2015; Mutisya et al., 2016). However, a few issues exist with implementing this technique. The use of small-mesh insect-proof netting can control the invasion of small insects but also affects greenhouse ventilation (Ajwang and Tantau, 2005), elevating the temperature and resulting in the rapid growth of vegetables. The use of larger-mesh netting does not provide effective prevention, and viral disease spreads as soon as B. tabaci infest the greenhouse. Currently, no reported study exists on controlling whitefly in China within tomato overwintering greenhouses that resolves the issue of ventilation when greenhouse aeration openings are covered with screens. The goal of the present study was to solve the issue of ventilation that prevents the use of insect-proof nets as a physical control measure by modifying the ventilation through the back wall of greenhouses within the structural context of the traditional solar greenhouse in China.

\section{MATERIALS AND METHODS}

\section{Indoor tests}

Simple white netting made of knitted polyester was obtained from a local market and used to construct nets for constraining insect movement. Four netting meshes were used: 40, 60, 80, and 100, with mesh diameters of 0.417 , $0.246,0.106$, and $0.028 \mathrm{~mm}$, respectively. Release cages: Thin wires were shaped into cylindrical frames (30-cm diameter, 40-cm height) that were covered by netting having one of the above four mesh sizes. The connecting seams were tightly sealed to convert the cylinders into release cages, and adult $B$. tabaci were placed in the cages. Rearing cages: Insect-proof, 100-mesh netting and PVC pipes (1.5-cm diameter) were used to construct square rearing cages $(80 \mathrm{~cm} \times 80 \mathrm{~cm} \times 80 \mathrm{~cm})$.

The release cages made with the 40,60,80, and 100 meshes were placed at the center of the rearing cages. A 3- to 4- leaf potted tobacco plant was placed at each of the four corners of the rearing cages. The adult $B$. tabaci that were placed in the release cages were within $24 \mathrm{~h}$ of eclosion and numbered 50 per cage. Each treatment, which consisted of the four different meshes used to construct the release cages, was repeated five times. The numbers of $B$. tabaci in the release cage and on the leaves of the tobacco plants were observed $24 \mathrm{~h}$ after the setup. The numbers obtained were then used to calculate the efficacy of the nets in constraining B. tabaci movement.

\section{Field tests}

The test site was located at Dongliangfu Village (3554'26” N, 117¹1'1” E), Tai'an City, Shandong Province, China. Four traditional tomato solar greenhouses with consistent structures were selected for testing. The 
greenhouse tents used for testing were $12 \mathrm{~m}$ wide, supported by a steel frame, and oriented in a north-south direction. The length of the tents was $60 \mathrm{~m}$, and their greatest internal height was $4.5 \mathrm{~m}$. The back walls were $3.5 \mathrm{~m}$ in height and were constructed of adobe. The greenhouses had front and upper ventilation. The growing space of each greenhouse was approximately $700 \mathrm{~m}^{2}$. The tomato (Solanum lycopersicum L. var. lycopersicum) variety planted was 'Jinpeng- 8 '. The insect-proof netting was cut into sections $60 \mathrm{~m}$ in length and $1.5 \mathrm{~m}$ in width for installation over the front and upper ventilation areas in the treatments described in the next paragraph. A total of 12 PVC pipes ( $30 \mathrm{~cm}$ diameter; $1 \mathrm{~m}$ length) were installed through holes drilled through the back wall of greenhouse III, $1.4 \mathrm{~m}$ above ground, with a $2.5 \mathrm{~m}$ spacing between two adjacent pipes. Each pipe was sealed with 80-mesh netting on both ends (Figure 1). During $3 \mathrm{yr}$, pest control has been applied with uniform criteria in the greenhouses, according to local practices.

Figure 1. Structure diagram of the greenhouse III.

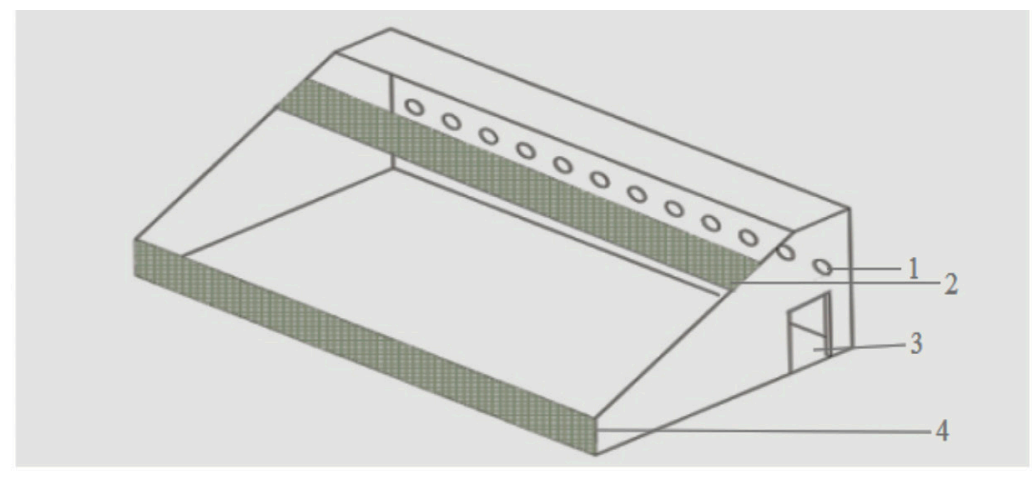

1) Adding vent-pipe in the back wall; 2) covering the front vent with 80-mesh net;

3) greenhouse entrance; 4) covering the upper vent with 80-mesh net.

\section{First test (2014)}

The first test was conducted between 24 August and 11 November 2014. The treatments consisted of control greenhouse (CK), a regular, untreated, solar greenhouse; greenhouse I treated with a 60-mesh section of netting installed over the front and upper ventilation areas but no added ventilation on the back wall; and greenhouse II, which duplicated greenhouse I except for the use of 80- rather than 60-mesh netting. The degree of the number of $B$. tabaci and the ToCV infection rate were determined as well as the greenhouse temperature and humidity.

\section{Second and third test (2015 and 2016)}

Because of the simple act of installing netting in greenhouses could elevate greenhouse temperature in first test (2014), we improved the experimental design in 2015 and 2016. The second test was conducted between 25 August and 11 November 2015 and the third test replicated it in 2016. Greenhouse III was treated with not only the 80-mesh netting installed over the front and upper ventilation areas but also added ventilation on the back wall. The degree of the number of $B$. tabaci and the ToCV infection rate were investigated in control greenhouse, greenhouse I and greenhouse III. The temperature and humidity of greenhouses II and III were also monitored.

\section{Method of investigation}

The occurrence of ToCV and population dynamics of B. tabaci in the solar greenhouses were studied at fixed spots on fixed plants. On the east and west sides of the greenhouses, four ridges of tomato plants were kept as guard rows. The tomato plants in the center rows were evenly split into five small zones. Six different spots in each small zone were sampled (one spot at each of the south, center, and north positions of two tomato rows were selected). At each spot, two representative tomato plants were selected. During the early growth stages, the entire plant was 
investigated. During the later stages, five leaves were selected from the upper plant region, and another five were sampled in the center area. This investigation was performed approximately every $10 \mathrm{~d}$. The number of $\mathrm{B}$. tabaci and the disease condition of the plant were recorded during each investigation. Additionally, leaves of labelled tomato plants were collected for a polymerase chain reaction (PCR) laboratory analysis of the virus-carrying rate of the plants. A temperature and humidity recorder was suspended at the center of each solar greenhouse $1.8 \mathrm{~m}$ above ground, and the temperature together with the relative humidity was automatically recorded daily at 30-min intervals starting at 00:00 h. From all the data recorded since the planting day, the temperature and daily relative humidity from 10:00-16:00 h were selected every $5 \mathrm{~d}$ for statistical analysis.

\section{Examination of the virus-carrying rate of plants}

Leaves suspected to be infected with virus were collected. A 0.1-g aliquot of the collected leaves was added to liquid nitrogen and ground to a powder. RNA was extracted from the powder following the protocol of a plant RNA extraction kit. The following formula was used for a $20-\mu \mathrm{L}$ reverse transcription system: $10 \mu \mathrm{L}$ template RNA, 1 $\mu \mathrm{L}$ arbitrary primer, $1 \mu \mathrm{L}$ dNTP, $1 \mu \mathrm{L}$ reverse transcriptase, $4 \mu \mathrm{L}$ reverse transcription solvent, and $3 \mu \mathrm{L}$ RNase-free double-distilled water $\left(\mathrm{ddH}_{2} \mathrm{O}\right)$. All the reagents were gently mixed and carried through the following reaction steps: $25^{\circ} \mathrm{C}$ for $10 \mathrm{~min}, 50{ }^{\circ} \mathrm{C}$ for $45 \mathrm{~min}$, and $85^{\circ} \mathrm{C}$ for $5 \mathrm{~min}$. Once the reaction steps were completed, the cDNA was stored at $-20{ }^{\circ} \mathrm{C}$.

For the PCR, ToCV-specific primers synthesized by the Sangon Biotech Co. (Shanghai, China) were employed. An upstream primer, 5'-ATGGAGAACAGTGCTGTT-3', and a downstream primer, 5'-TAGCAACCAGTTATCGATGC-3', were employed during amplification. A $10-\mu \mathrm{L}$ reaction system was composed of $2 \mu \mathrm{L}$ cDNA, $0.5 \mu \mathrm{L}$ each of the upstream and downstream primers, $5 \mu \mathrm{L} 2 \times$ PCR Master Mix, and 2

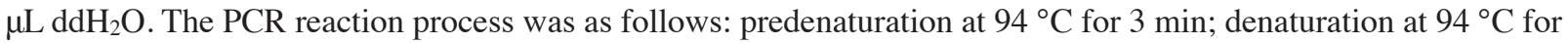
$50 \mathrm{~s}$, annealing at $50{ }^{\circ} \mathrm{C}$ for $50 \mathrm{~s}$, and extension at $72{ }^{\circ} \mathrm{C}$ for $90 \mathrm{~s}$, repeated for 35 cycles; and extension at $70{ }^{\circ} \mathrm{C}$ for $10 \mathrm{~min}$. The PCR amplification products were subjected to electrophoresis using $1.5 \%$ agarose gel, and the results were photographed.

\section{Statistical analyses}

The numbers of $B$. tabaci adults on plants and the numbers of incidence plants from all the different treatments were subjected to ANOVA using SPSS software (Version 20.0; IBM Corporation, Armonk, New York, USA), and treatment means that showed significant difference at the F test separated using Tukey's honestly significant difference (Tukey's HSD) test at $\mathrm{p} \leq 0.05$.

\section{RESULTS}

\section{Indoor tests to select the mesh size of insect-proof netting for field use}

The 80- and 100-mesh insect-proof nettings better segregated $\mathrm{B}$. tabaci, providing respective protection levels of 98.4\% and 100\% compared with 57.2\% and almost no protection for the 60- and 40-mesh nettings, respectively. Considering these data and the ventilation issues associated with fine screens, the 80- and 60-mesh insect-proof nettings were selected for our studies on the control of B. tabaci in greenhouses (Figure 2).

\section{Temperature and humidity of the solar greenhouses}

The average daily temperatures from 10:00-16:00 h between 25 August and 29 October 2014 were 31.42, 29.03, and $27.91{ }^{\circ} \mathrm{C}$ for greenhouses II, I, and CK, respectively. The difference in the average temperatures of greenhouses II and CK was $3.51^{\circ} \mathrm{C}$, compared with $1.12^{\circ} \mathrm{C}$ for greenhouses I and CK. Thus, the covering of ventilation openings with netting increased the internal temperature of the greenhouses; and the temperature elevation was even more apparent when using the 80 - compared with the 60 -mesh netting. The changes in relative humidity were approximately the same for greenhouses CK, I, and II during the same period. However, from 4 October-8 November 2014, the changes in relative humidity differed among the greenhouse treatments, with the humidity of greenhouse II higher than that of greenhouse CK by an amount ranging from $2.16 \%-20.94 \%$. The difference between greenhouse I and 
Figure 2. Isolation effect to Bemisia tabaci adults of different insect-proof nets.

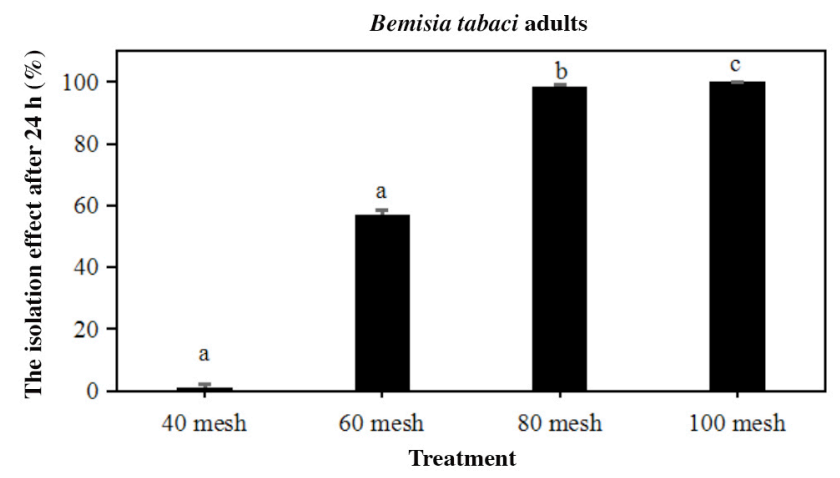

Means followed by the same letter within an evaluation date are nonsignificantly different according to Tukey's honestly significant difference (THSD) test at $(\mathrm{p} \leq 0.05)$.

II was less and ranged from $0.67 \%-6.09 \%$. During the investigation period, the average relative humidity was more stable in greenhouse II relative to the other greenhouses.

After adding ventilation to the back wall of the greenhouse, the maximum temperature in 2015 was $32.7^{\circ} \mathrm{C}$, and that in 2016 was $32.98^{\circ} \mathrm{C}$. For greenhouse II, the average temperature from 10:00-16:00 h reached a maximum of $37.56^{\circ} \mathrm{C}$ in 2015 and $38.51^{\circ} \mathrm{C}$ in 2016 . From 25 August to 29 October 2015, the average temperature in greenhouse III was $26.55{ }^{\circ} \mathrm{C}$, which was $7.27^{\circ} \mathrm{C}$ lower than that of greenhouse II. From 20 August to 29 October 2016, the average temperature in greenhouse III was $27.11{ }^{\circ} \mathrm{C}$, which was $5.63{ }^{\circ} \mathrm{C}$ lower than that of greenhouse II. The environmental temperature dropped at the beginning of November. The ventilation on the back wall of greenhouse III was then sealed; the temperature changes in the two greenhouses reached the same level. In 2015 and 2016, little difference in the change in the average daily relative humidity occurred between greenhouses II and III; this difference ranged between $0 \%$ and $6.01 \%$ (Figures 3 and 4).

\section{Effects of different treatments on the number of Bemisia tabaci}

During the 2014 investigation period, the number of adult $B$. tabaci in the CK treatment increased rapidly within the $20 \mathrm{~d}$ after tomato planting, reaching a maximum of 14.08 insects per plant on 13 September. On 22 September and 9 October, the application of isoprocarb smoke agent (o-cumenyl methylcarbamate; $15 \%$ smoke agent, a product of Henan Chunguang Agrochemical Co.; Henan, China) was utilized for control. The number of adult insects dropped significantly within $48 \mathrm{~h}$ after treatment but increased shortly thereafter. The number of $B$. tabaci on tomato was less in greenhouse II than in greenhouses CK and I. In greenhouse II, the maximum average number of insects was 0.47 insects per plant and the minimum was 0.3 insects per plant; the protective effect was significant even without the use of insecticide. The number of insects in greenhouse I was slightly less than that in greenhouse CK. However, the maximum average number still reached 4.45 insects per plant. After the treatment with isoprocarb smoke agent on 22 September, the minimum average was 0.32 insects per plant. This protective effect was worse than that shown by the greenhouse II treatment.

During the 2015 investigation period, the number of $B$. tabaci in greenhouse III was kept at a relatively low level. The maximum average number of insects was 0.33 insects per plant, and the minimum was 0.07 insects per plant. For greenhouse CK during the same investigation period, the maximum was 6.37 insects per plant; isoprocarb smoke agent treatment was implemented on 11 September and 9 October. For greenhouse I, the maximum was 3.07 insects per plant, and isoprocarb smoke agent treatment was implemented on 11 September. During the 2016 investigation period, the number of B. tabaci in greenhouse III was 0.25 and 0.03 insects per plant at its maximum and minimum, respectively. For greenhouse CK, the maximum reached 11.93 insects per plant; this greenhouse was treated with isoprocarb smoke agent on 14 September and 3 October. For greenhouse I, the maximum reached 6.38 insects per plant; this greenhouse was treated with isoprocarb smoke agent on September 14. The population dynamic of B. tabaci in the greenhouses in 2016 was approximately the same as that in 2015 (Figures 5). 
Figure 3. Variation of average temperature of different greenhouses during 10:00-16:00 h.

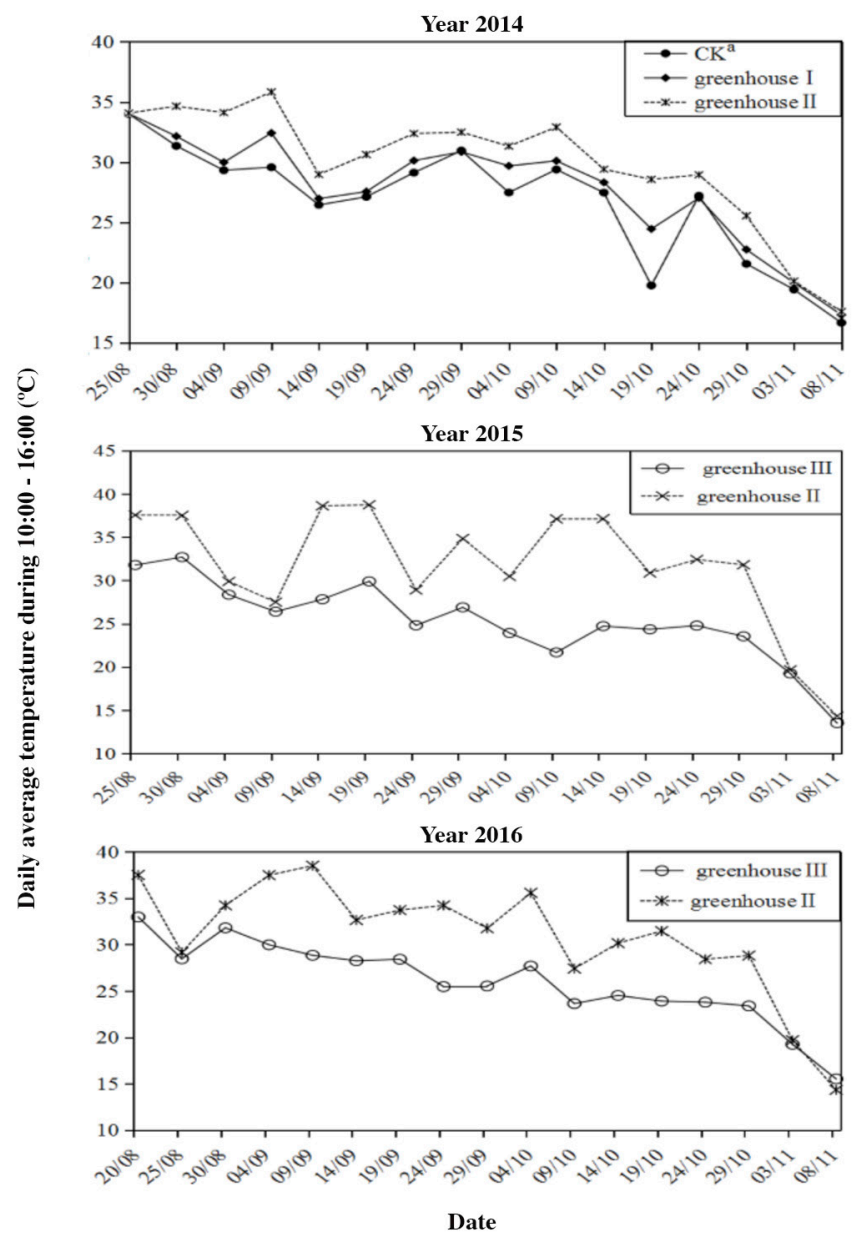

${ }^{\mathrm{a}} \mathrm{CK}$ : Control check indicates a regular untreated solar greenhouse.

\section{Effects of different treatments on the ToCV infection of tomato plants}

As seen from the field study results, ToCV infections on tomato plants were found earlier for the CK treatment than for the other greenhouse treatments, and the CK infection was the most severe. In 2014, two infected plants were found $20 \mathrm{~d}$ after tomato planting in greenhouse CK. In greenhouse I, three infected plants were found $30 \mathrm{~d}$ after planting. The infection rate gradually increased as the interval after planting lengthened. The rate of increase was more rapid in greenhouse CK than in greenhouse I. In greenhouse II, one infected plant was found $70 \mathrm{~d}$ after sowing. In 2014, the infection rate in the greenhouses $80 \mathrm{~d}$ after tomato planting was $80 \%, 58.33 \%$, and $5 \%$ for greenhouses CK, I, and II, respectively. In 2015, the infection rate in the greenhouses $80 \mathrm{~d}$ after tomato planting was $76.67 \%, 53.33 \%$, and $6.67 \%$ for greenhouses CK, I, and II, respectively. In 2016, the respective infection rates $90 \mathrm{~d}$ after planting were $75 \%, 58.33 \%$, and $6.67 \%$ for greenhouses CK, I, and II. The differences in infection rates were significant. Additionally, the plants judged in the field to be infected were brought to the laboratory for the detection of virus. This analysis confirmed that the plants were infected with ToCV (Tables 1,2 and 3).

\section{DISCUSSION}

Recently, ToCV has spread rapidly in multiple provinces of China, adding to the critically important viruses affecting Chinese vegetable production. The prevention of ToCV infection is essential (Zhou et al., 2014). Currently, no virusresistant species yet exists worldwide. Controlling the virus vector, B. tabaci, is an important method for controlling 
Figure 4. Variation of the average relative humidity of different greenhouses.

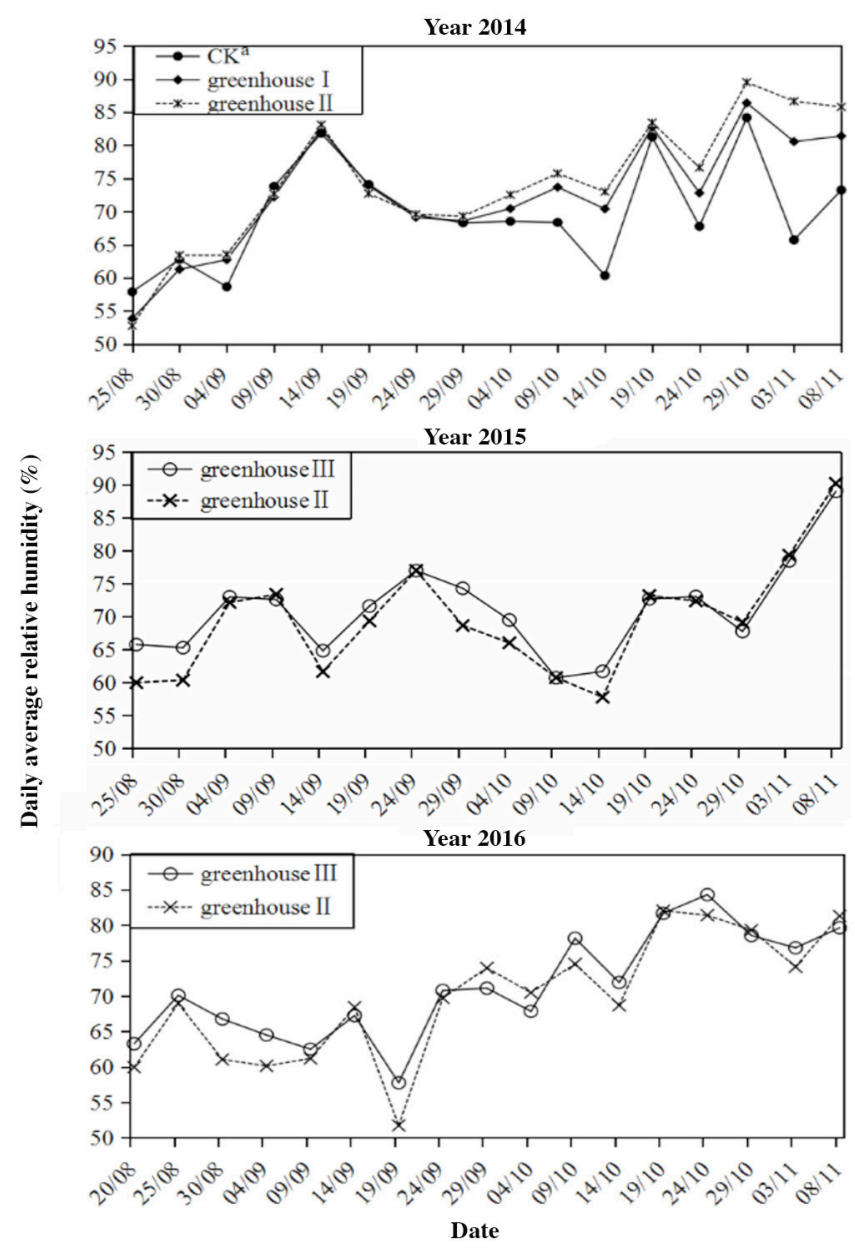

${ }^{\mathrm{a} C K}$ : Control check indicates a regular untreated solar greenhouse.

the spread of ToCV (Dai et al., 2016). Our study found through the investigation conducted in 2014-2015 that the ToCV infection rate of tomato plants in the Tai' an area, Shandong Province, China, increased as the number of $B$. tabaci increased. The weather conditions in August-September are advantageous for the mass reproduction of $B$. tabaci. Therefore, these months are the peak time for the occurrence of ToCV infections; this pattern is consistent with the occurrence of ToCV in Shandong Province in 2013 (Liu et al., 2014). ToCV shows the characteristics of a latent infection; symptoms are unobservable until $3 \mathrm{wk}$ after infection in seedlings (Wintermantel and Wisler, 2006). In greenhouse I, the number of $B$. tabaci apparently dropped in late October. However, the control of the $B$. tabaci infestation was not well executed, resulting in a continuously increasing viral infection rate in tomato plants. Such a result suggests that the key to preventing viral infection is the control of $B$. tabaci infestations during the tomato growth period.

Segregation by insect-proof netting is a critical measure in pest control that can effectively suppress the occurrence of viral infection in vegetables (Huang et al., 2013). In our study, various netting mesh sizes were tested for their effectiveness in creating segregation. The widely utilized, 60-mesh insect-proof netting could only provide a $57.2 \%$ level of protection against B. tabaci, whereas the respective levels were $98.4 \%$ and $100.0 \%$ for the 80 - and 100 mesh nettings, respectively. The field test results indicate that the protection provided was significantly better for the 80-mesh compared with the 60-mesh netting. In our studies, 80-mesh netting was employed as an insect shield from the day of planting, with the objective of ensuring a virus-free plant condition during the seedling and growth periods; this shield significantly reduced the virus infection rate in tomatoes. The results of research by Wang (2013) 
Figure 5. Population dynamics of Bemisia tabaci on tomato in greenhouse.

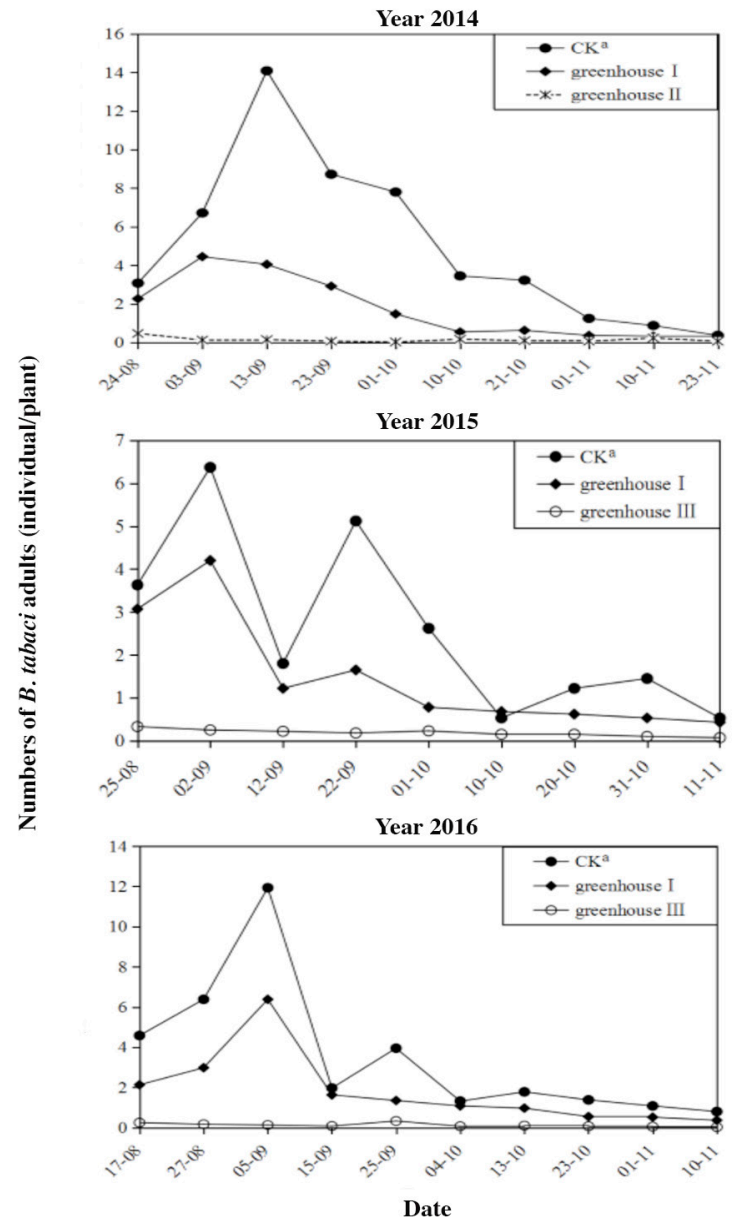

${ }^{\mathrm{a}} \mathrm{CK}$ : Control check indicates a regular untreated solar greenhouse.

Table 1. Tomato chlorosis virus infection of tomato plant in greenhouse in 2014.

\begin{tabular}{lccc}
\hline & \multicolumn{3}{c}{ Tomato plant infected rate $(\%)^{\mathrm{a}}$} \\
\cline { 2 - 4 } Investigation time & $\mathrm{CK}^{\mathrm{b}}$ & Greenhouse I & Greenhouse II \\
\hline 24 Aug 2014 & 0 & 0 & 0 \\
3 Sept 2014 & 0 & 0 & 0 \\
13 Sept 2014 & $3.32 \pm 2.03 \mathrm{a}$ & $0.00 \pm 0.00 \mathrm{a}$ & $0.00 \pm 0.00 \mathrm{a}$ \\
23 Sept 2014 & $8.33 \pm 3.73 \mathrm{a}$ & $4.99 \pm 3.33 \mathrm{a}$ & $0.00 \pm 0.00 \mathrm{a}$ \\
1 Sept 2014 & $16.67 \pm 4.56 \mathrm{a}$ & $10.00 \pm 4.86 \mathrm{ab}$ & $0.00 \pm 0.00 \mathrm{~b}$ \\
10 Oct 2014 & $38.33 \pm 5.00 \mathrm{a}$ & $18.33 \pm 4.08 \mathrm{~b}$ & $0.00 \pm 0.00 \mathrm{c}$ \\
21 Oct 2014 & $46.67 \pm 5.65 \mathrm{a}$ & $26.67 \pm 6.12 \mathrm{~b}$ & $0.00 \pm 0.00 \mathrm{c}$ \\
1 Nov 2014 & $61.67 \pm 8.16 \mathrm{a}$ & $38.33 \pm 8.98 \mathrm{~b}$ & $1.67 \pm 1.67 \mathrm{c}$ \\
10 Nov 2014 & $80.00 \pm 6.24 \mathrm{a}$ & $58.33 \pm 10.54 \mathrm{a}$ & $5.00 \pm 3.33 \mathrm{~b}$ \\
\hline
\end{tabular}

Means followed by the same letter within an evaluation date are nonsignificantly different according to Tukey's honestly significant difference (THSD) test at ( $\mathrm{p} \leq 0.05)$.

${ }^{a}$ Tomato plant infected rate $(\%)=$ number of infected plants/number of investigated plants.

${ }^{\mathrm{b}} \mathrm{CK}$ : Control check indicates a regular untreated solar greenhouse. 
Table 2. Tomato chlorosis virus infection of tomato plant in greenhouse in 2015.

\begin{tabular}{lccc}
\hline & \multicolumn{3}{c}{ Tomato plant infected rate $(\%)^{\mathrm{a}}$} \\
\cline { 2 - 4 } Investigation time & $\mathrm{CK}^{\mathrm{b}}$ & Greenhouse I & Greenhouse II \\
\hline 25 Aug 2015 & 0 & 0 & 0 \\
2 Sept 2015 & 0 & 0 & 0 \\
12 Sept 2015 & $5.00 \pm 3.33 \mathrm{a}$ & $0.00 \pm 0.00 \mathrm{a}$ & $0.00 \pm 0.00 \mathrm{a}$ \\
22 Sept 2015 & $13.33 \pm 5.65 \mathrm{a}$ & $3.33 \pm 2.04 \mathrm{ab}$ & $0.00 \pm 0.00 \mathrm{~b}$ \\
1 Sept 2015 & $25.00 \pm 5.89 \mathrm{a}$ & $8.33 \pm 2.64 \mathrm{~b}$ & $0.00 \pm 0.00 \mathrm{~b}$ \\
10 Sept 2015 & $45.00 \pm 2.04 \mathrm{a}$ & $16.67 \pm 4.56 \mathrm{~b}$ & $0.00 \pm 0.00 \mathrm{c}$ \\
20 Sept 2015 & $51.67 \pm 4.86 \mathrm{a}$ & $30.00 \pm 5.65 \mathrm{~b}$ & $0.00 \pm 0.00 \mathrm{c}$ \\
31 Sept 2015 & $63.33 \pm 6.77 \mathrm{a}$ & $40.00 \pm 3.12 \mathrm{~b}$ & $3.33 \pm 2.04 \mathrm{c}$ \\
11 Sept 2015 & $76.67 \pm 6.12 \mathrm{a}$ & $53.33 \pm 3.33 \mathrm{~b}$ & $6.67 \pm 3.12 \mathrm{c}$ \\
\hline
\end{tabular}

Means followed by the same letter within an evaluation date are nonsignificantly different according to Tukey's honestly significant difference (THSD) test at $(\mathrm{p} \leq 0.05)$.

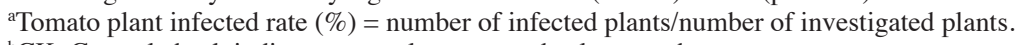

${ }^{\mathrm{b}} \mathrm{CK}$ : Control check indicates a regular untreated solar greenhouse.

Table 3. Tomato chlorosis virus infection of tomato plant in greenhouse in 2016.

\begin{tabular}{lccc}
\hline & \multicolumn{3}{c}{ Tomato plant infected rate $(\%)^{\mathrm{a}}$} \\
\cline { 2 - 4 } Investigation time & $\mathrm{CK}^{\mathrm{b}}$ & Greenhouse I & Greenhouse II \\
\hline 17 Aug 2016 & 0 & 0 & 0 \\
27 Aug 2016 & 0 & 0 & 0 \\
5 Sept 2016 & 0 & 0 & 0 \\
15 Sept 2016 & $5.00 \pm 3.33 \mathrm{a}$ & $1.67 \pm 1.67 \mathrm{a}$ & $0.00 \pm 0.00 \mathrm{a}$ \\
25 Sept 2016 & $13.33 \pm 3.33 \mathrm{a}$ & $6.66 \pm 1.67 \mathrm{~b}$ & $0.00 \pm 0.00 \mathrm{c}$ \\
4 Oct 2016 & $28.33 \pm 3.33 \mathrm{a}$ & $15.00 \pm 3.12 \mathrm{~b}$ & $0.00 \pm 0.00 \mathrm{c}$ \\
13 Oct 2016 & $36.67 \pm 2.04 \mathrm{a}$ & $28.33 \pm 2.04 \mathrm{~b}$ & $0.00 \pm 0.00 \mathrm{c}$ \\
23 Oct 2016 & $56.67 \pm 3.12 \mathrm{a}$ & $41.67 \pm 3.73 \mathrm{~b}$ & $0.00 \pm 0.00 \mathrm{c}$ \\
1 Nov 2016 & $65.00 \pm 4.08 \mathrm{a}$ & $50.00 \pm 5.27 \mathrm{~b}$ & $3.33 \pm 2.04 \mathrm{c}$ \\
10 Nov 2016 & $75.00 \pm 5.27 \mathrm{a}$ & $58.33 \pm 4.56 \mathrm{~b}$ & $6.67 \pm 3.12 \mathrm{c}$ \\
\hline
\end{tabular}

Means followed by the same letter within an evaluation date are nonsignificantly different according to Tukey's honestly significant difference (THSD) test at ( $\mathrm{p} \leq 0.05)$.

aTomato plant infected rate $(\%)=$ number of infected plants/number of investigated plants.

${ }^{\mathrm{b}} \mathrm{CK}$ : Control check indicates a regular untreated solar greenhouse.

indicated that 100-mesh insect-proof netting could significantly reduce the occurrence of Tomato yellow leaf curl virus (TYLCV). Such a result is consistent with the findings in our study suggesting that the use of insect-proof netting during the growth period could block the intrusion of virus-carrying $B$. tabaci. The number of infected tomato plants during the growth period could be effectively decreased by blocking the path of viral spread from an external source into the solar greenhouses.

The autumn planting of tomato mainly occurs in early to mid-August for solar greenhouses in northern China, including Shandong Province. After planting and until the end of September, the temperature in the greenhouses is slightly heightened during the day. The use of insect-proof nets can affect the greenhouse ventilation. In our study, 80-mesh netting was implemented. During the investigation period, the maximum greenhouse temperature during the day could reach $47.1^{\circ} \mathrm{C}$. High temperatures can yield disadvantageous effects on the growth of vegetables (Zhang et al., 2005; Zhao et al., 2010). Therefore, in our study, the greenhouse ventilation was modified on the back wall of the solar greenhouse. The experimental results indicate that increased ventilation on the back wall significantly reduced the internal temperature of greenhouses shielded from insects by netting to ensure the normal growth of tomato. During the middle to end of October, the temperature insulating effect was not influenced after sealing the ventilation. Unsealing the ventilation during the next May restored the cooling effect. In mid-November 2015 , the ToCV infection rate in greenhouse III was only $6.67 \%$, whereas that for greenhouse I was $53.33 \%$, and that for greenhouse $\mathrm{CK}$ was as high as $76.6 \%$. The modified greenhouse ventilation allowed the full protection provided by the insect-proof netting. This technique of modifying the ventilation on the back wall of traditional solar-powered 
greenhouses provided a good solution to the high-temperature issue during the fall season that prevents the use of insect-proof netting. We also observed that the netting should be installed before the planting of vegetables and that the human transport of $B$. tabaci into greenhouses should be avoided to obtain a satisfactory outcome.

\section{CONCLUSION}

In conclusion, insect-proof netting with an 80-mesh size provided a 98.4\% level of protection against Bemisia tabaci. Considering ventilation, 80 -mesh netting is more suitable than 100 -mesh or 60 -mesh netting for field use. However, the simple act of installing netting in greenhouses could elevate greenhouse temperature. After installing 80-mesh insect-proof netting at the front and upper ventilation areas as well as adding a ventilating pipeline to the back wall, the number of B. tabaci was effectively reduced, and Tomato chlorosis virus damage was prevented. This technique is recommended for implementation in solar greenhouses.

\section{ACKNOWLEDGEMENTS}

This work was financially supported by the Shandong Science and Technology Development Plan (2012GNC11007) and Shandong Agricultural Technology Innovation Project. The authors thank all the workers for assistance in conducting this research.

\section{REFERENCES}

Ajwang, P.O., and Tantau, H.J. 2005. Prediction of the effect of insect-proof screens on climate in a naturally ventilated greenhouse in humid tropical climates. Acta Horticulturae 691:449-456.

Boykin,L.M., Shatters Jr, R.J., Rosell, R.C., McKenzie, C.L.,Ann Bagnall, R., De Barro, P., et al. 2007. Global relationships of Bemisia tabaci (Hemiptera: Aleyrodidae) revealed using Bayesian analysis of mitochondrial COI DNA sequences. Molecular Phylogenetics and Evolution 44(3):1306-1319.

Byrne, D.N., and Bellows, Jr.T.S. 1991. Whitefly biology. Annual Review of Entomology 36(36):431-457.

Cahill, M., Denholm, I., Ross, G., Gorman, K., and Johnston, D. 1996. Relationship between bioassay data and the simulated field performance of insecticides against susceptible and resistant Bemisia tabaci. Bulletin of Entomological Research 86(2):109-116.

Dáder, B., Legarrea, S., Moreno, A., Plaza, M., Sousa, M.C., Amor, F., et al. 2015. Control of insect vectors and plant viruses in protected crops by novel pyrethroid-treated nets. Pest Management Science 71(10):1397-1406.

Dai, H.J., Liu, Y.G., Zhu, X.P., Liu, Y.J., and Zhao, J. 2016. Tomato chlorosis virus (ToCV) transmitted by Bemisia tabaci biotype Q of Shouguang in Shandong Province. Journal of Plant Protection 43(1):162-167.

De Barro, P.J., Liu, S.S., Boykin, L.M., and Dinsdale, A.B. 2011. Bemisia tabaci: A statement of species status. Entomology 56:1-19.

Dinsdale, A., Cook, L., Riginos, C., Buckley, Y.M., and De Barro, P. 2010. Refined global analysis of Bemisia tabaci (Hemiptera: Sternorrhyncha: Aleyrodoidea: Aleyrodidae) mitochondrial cytochrome oxidase 1 to identify species level genetic boundaries. Annals of the Entomological Society of America 103(2):196-208.

Fernández, E., Grávalos, C., Haro, P.J., Cifuentes, D., and Bielza, P. 2009. Insecticide resistance status of Bemisia tabaci Q-biotype in south-eastern Spain. Pest Management Science 65(8):885-891.

Gu, X.S., Bu, W.J., Xu, W.H., Bai, Y.C., Liu, B.M., and Liu, T.X. 2008. Population suppression of Bemisia tabaci (Hemiptera: Aleyrodidae) using yellow sticky traps and Eretmocerus nr. rajasthanicus (Hymenoptera: Aphelinidae) on tomato plants in greenhouses. Insect Science 15(3):263-270.

Hu, J., Barro, P.D., Zhao, H., Wang, J., Nardi, F., and Liu, S.S. 2011. An extensive field survey combined with a phylogenetic analysis reveals rapid and widespread invasion of two Alien whiteflies in China. PLoS ONE 6(1):e16061.

Huang, B.H., Lin, G.K., Wang, X.H., and Zhang, X.F. 2013. Control effects of fly nets to the pests of vegetables in greenhouses. Plant Protection 39(6): 164-169.

Karwitha, M., Feng, Z., Yao, M., Chen, X.J., Zhang, W.N., Liu, X.F., et al. 2014. The complete nucleotide sequence of the RNA 1 of a Chinese isolate of Tomato chlorosis virus. Journal of Phytopathology 162(6):411-415.

Liu, Y.G., Wei, J.P., Qiao, N., Li, M.Q., Liu, X.M., and Zhu, X.P. 2014. The outbreaks and control measures of Tomato chlorosis virus in Shandong Province. China Vegetables 5:67-69.

Luo, C., Jones, C.M., Devine, G., Zhang, F., Denholm, I., and Gorman, K. 2010. Insecticide resistance in biotype Q (Hemiptera: Aleyrodidae) from China. Crop Protection 29(5):429-434. 
Mutisya, S., Saidi, M., Opiyo, A., Ngouajio, M., and Martin, T. 2016. Synergistic effects of agronet covers and companion cropping on reducing whitefly infestation and improving yield of open field-grown tomatoes. Agronomy 6(3):42.

Saidi, M., Gogo, E.O., Itulya, F.M., Martin, T., and Ngouajio, M. 2013. Microclimate modification using eco-friendly nets and floating row covers improves tomato (Lycopersicon esculentum) yield and quality for small holder farmers in East Africa. Agricultural Sciences 4(11):577-584.

Schuster, D.J., Mann, R.S., Toapanta, M., Cordero, R., Thompson, S., Cyman, S., et al. 2010. Monitoring neonicotinoid resistance in biotype B of Bemisia tabaci in Florida. Pest Management Science 66(2):186-195.

Sun, G.Z., Gao, L.L., Lu, W.L., Wang, Y., Zhang, A.S., and Zhu, X.P. 2015. Molecular detection and identification of Tomato chlorosis virus infecting greenhouse-grown tomato plants in Hebei Province. Northern Horticulture 9:95-98.

Tsai, W.S., Shih, S.L., Green, S.K., Hanson, P., and Liu, H.Y. 2004. First report of the occurrence of Tomato chlorosis virus and tomato infectious chlorosis virus in Taiwan. Plant Disease 88(3):311.

Wang, C.X. 2013. Control research of different physical measures on Bemisia tabaci and tomato TY virus disease. Journal of the Staff and Worker's University 4:100-102.

Wang, Z.Y., Yan, H.F., Yang, Y.H., and Wu, Y.D. 2010. Biotype and insecticide resistance status of the whitefly Bemisia tabaci, from China. Pest Management Science 66(12):1360-1366.

Wintermantel, W.M., and Wisler, G.C. 2006. Vector specificity, host range, and genetic diversity of Tomato chlorosis virus. Plant Disease 90(6):814-819.

Wisler, G.C., Li, R.H., Liu, H.Y., Lowry, D.S., and Duffus, J.E. 1998. Tomato chlorosis virus: a new whitefly-transmitted, phloem-limited, bipartite closterovirus of tomato. Phytopathology 88(5):402-409.

Zhang, J., Li, T.L., and Xu, J. 2005. Effects of daytime sub-high temperature on greenhouse tomato growth, development, yield and quality. Chinese Journal of Applied Ecology 16(6):1051-1055.

Zhao, L.M., Li, G., Gao, Y., Liu, Y.J., Sun, G.Z., and Zhu, X.P. 2014. Molecular detection and complete genome sequences of Tomato chlorosis virus, isolates from infectious outbreaks in China. Journal of Phytopathology 162(10):627-634.

Zhao, R.N., Wang, R., Wang, N., Fan, Z.F., and Zhou, T. 2013. First report of Tomato chlorosis virus in China. Plant Disease 97(8):1123.

Zhao, Y.P., Zou, Z.R., Bai, P.W., Ren, L., and Li, P.F. 2010. Effect of different temperature on the growth and yield of tomato in greenhouse. Acta Agriculture Boreali-occidentalis Sinica 19(2):133-137.

Zhou, T., Yang, P.Y., Zhao, R.N., Shi, Y.C., Yuan, K., and Fan, Z.F. 2014. Alarming the transmission and damage of Tomato chlorosis virus in China. Plant Protection 5:196-199.

Zhu, L., Wang, Z.H., Gong, Y.J., Ren, Z.H., Jin, G.H., Chen, J.C., et al. 2016. Efficiency of UV-absorbing film in the management of pest insects and its effects on the growth and quality of eggplants. Acta Entomologica Sinica 59(2):227-238. 